\title{
Analisa Konsep Koping : Suatu Pengantar
}

\section{ACHIR YANI S HAMID}

Analisa konsep koping merupakan suatu upaya membahas phenomena-phenomena yang mendasari mekanisme pertahanan diri. Pada penelitian yang dilakukan banyak difokuskan pada perilaku, strategi dan gaya koping dibandingkan penggunaan yang tepat istilah pola koping. Hasil penelitian menunjukkan mekanisme koping mempunyai hasil positif dan negatif dan memberikan dampak yang sejalan terhadap penanganan stres yang menimbulkan koping tersebut.

Pembahasan konsep koping sangat penting karena dapat membantu kemampuan klien dalam membatasi masalah dengan menggunakan strategi koping yang paling efektif.

Kata kunci : penyebab stress, depresi, mekanisme pertahanan diri, respon adaptasi.

Consept coping analyzes is an effort to discuss the phenomena which contribute basicly for defence mechanism behavior. The research have focused to attitude, strategic and patern of coping. The result show coping mechanism has positive or negative efect, and give an appropriate influence to the problem solving style.

Key word : stressor, depression, defence mechanism, adaptif response. 